\title{
O (nie)tożsamości pojęć JĘZYK SPECJALISTYCZNY, JĘZYK SPECJALNY, JĘZYK FACHOWY, JĘZYK PROFESJONALNY, JĘZYK ZAWODOWY, PROFESJOLEKT, TECHNOLEKT
}

\section{Wprowadzenie}

W polskojęzycznej literaturze lingwistycznej w odniesieniu do kodów stanowiących narzędzie porozumienia w różnych grupach specjalistów stosuje się rozmaite terminy, wśród których znajduje się siedem tytułowych form: język specjalistyczny, język specjalny, język profesjonalny, język fachowy, język zawodowy, profesjolekt i technolekt. Mnogość określeń nie jest bynajmniej zjawiskiem wyjątkowym, gdyż chociażby na gruncie niemieckim funkcjonuje cały szereg określeń odnoszących się do tego fenomenu: Fachsprache, Fachlekt, Berufssprache, Arbeitssprache, Fachjargon, Expertensprache, Sondersprache Spezialsprache, Technolekt ${ }^{1}$ (zob. np. Grucza S. 2008). Zastanawiający jest jednak fakt, że choć obserwujemy intensywny i systematyczny zarazem przyrost opracowań dotyczących wspomnianego wycinka rzeczywistości językowej, nie podjęto dotychczas kompleksowej próby wskazania zakresów poszczególnych pojęć, a tym samym określenia ich semantycznej tożsamości, styczności czy odrębności (por. Karwatowska, Jarosz 2013: 102). Do rzadkości należą starania Ewy Pajewskiej (2003: 13-27) czy Bronisławy Ligary (2011: 164-167) zmierzające do ustalenia charakteru relacji między wybranymi terminami. Badacze z jednej strony dostrzegają zatem nadmiar rozmaitych form (np. Gajewska, Sowa 2014: 17), jednak niestety często używają ich intuicyjnie, nie podejmując refleksji nad precyzyjnością formy czy jej adekwatnością do opisywanego zjawiska. Świadczyć to może natomiast o nieuświadamianiu sobie istnienia terminologicznego bałaganu, o niedostrzeganiu potrzeby jego opanowania albo

\footnotetext{
${ }^{1}$ Podobny nadmiar nazw cechuje m.in. angielski system terminologiczny (por. np. Nagy 2014).
} 
wreszcie o przyjmowaniu status quo i pozostawianiu misji porządkowania nazw innym. Opisywana sytuacja jest dość zaskakująca, jeśli weźmiemy pod uwagę, że lingwiści zajmujący się teorią języków specjalistycznych uznają ścisłość terminów używanych $\mathrm{w}$ danej dziedzinie nauki czy techniki za jeden $\mathrm{z}$ wyznaczników omawianych tu kodów (np. Lukszyn (red.) [2002] 2005: 151).

W zarysowanej perspektywie uporządkowanie tytułowych nazw wydaje się niezbędne zwłaszcza w obliczu zarówno pogłębiającej się dyferencjacji polszczyzny stanowiącej aktualny problem badawczy (np. Gajda 2005: 80), jak i szybkiego rozwoju lingwistyki języków specjalistycznych. Wymienne posługiwanie się rozmaitymi określeniami może wszak skutkować poważnymi nieporozumieniami, gdyż denotaty omawianych terminów — jak postaram się dowieść — nie są tożsame. Próbę wykazania semantycznej (nie)kompatybilności wymienionych w tytule form postaram się zrealizować etapowo: (1) w pierwszej kolejności przybliżę sens sformułowań w oderwaniu od ich teoretycznego obciążenia, tzn. zanalizuję ugruntowane w polszczyźnie ogólnej znaczenia poszczególnych składników; następnie zinterpretuję objaśnienia i cząstkowe uściślenia funkcjonujące w (2) słownikach zawierających terminologię lingwistyczną oraz w (3) opracowaniach; wreszcie (4) na podstawie poczynionych ustaleń podejmę próbę wytyczenia zakresów badanych nazw i określenia łączących ich relacji. W pełni podzielam bowiem stanowisko Stanisława Grabiasa ([1994] 2003: 123), który twierdził, że „,wszelkie dyskusje dotyczące problemów terminologicznych, pozbawione oparcia w jednoczesnej charakterystyce cech językowych i uwarunkowań społecznych, stają się dyskusjami jałowymi”.

\section{Analiza leksykalna}

Wśród siedmiu wybranych określeń większość stanowią nazwy dwuelementowe, zbudowane w upowszechniony w polskiej lingwistyce sposób, tzn. składające się z rzeczownika język i uściślającej przydawki. W takich połączeniach wyrazowych — jak wyjaśniał ponad pół wieku temu Zenon Klemensiewicz (1953: 7) — „rozumiemy człon pierwszy [...] jako skrót wyrażenia język polski podający genus proximum, a w członie drugim jest wskazana differentia specifica" (por. Grucza F. 2002: 15). Współcześnie zresztą za jedno ze znaczeń polisemicznego leksemu język uznaje się 'sposób porozumiewania się ludzi pewnego środowiska lub zawodu oraz zapisu i przekazywania informacji w jakiejś dziedzinie wiedzy' (Dubisz (red.) 2003 [1]: 1303), co dodatkowo uzasadnia użycie tego wyrazu w zestawieniach terminologicznych odnoszących się nie tylko do samej polszczyzny, ale też do funkcjonujących w jej obrębie wariantów. Z kolei jednoczłonowe nazwy profesjolekt i technolekt posiadające status internacjonalizmów ${ }^{2}$ zawierają niezwykle produktywny nie tylko na polskim gruncie człon -lekt ozna-

${ }^{2}$ Formy te funkcjonują bowiem m.in. w językach angielskim (professiolect, technolect), niemieckim (Professiolekt, Technolekt), francuskim (professiolecte, technolecte) czy słowackim (profesiolekt, technolekt) (zob. np. Giers 2017: 94; Vanneste 2005: 94). 
czający ‘język, mowę’ (zob. Polański (red.) [1993] 2003: 118; Piekot 2008: 32; por. Danesi 1985). Funkcję pierwiastków charakteryzujących desygnowany fenomen, czyli rodzaj narzędzia komunikacyjnego, pełnią zatem przymiotniki fachowy, profesjonalny, specjalistyczny, specjalny, zawodowy w zespoleniach oraz człon profesjo- (stanowiący podstawę wyrazów profesja, profesjonalny, profesjonalista itd.) i prefiks techno- stanowiące składniki derywatów z sufiksem -lekt.

Wydaje się, że wśród wynotowanych adjektywów najmniej precyzyjna jest forma specjalny, która w polszczyźnie ogólnej ma charakter polisemiczny: (1) 'odnoszący się do jednego wybranego przedmiotu, zagadnienia lub jednej osoby' oraz (2) 'wyjątkowy, szczególny, niecodzienny' ${ }^{3}$. Znaczenie tego słowa jest zatem mało wyraziste, niekonkretne, a tym samym sformułowanie język specjalny jest semantycznie nieostre. Należałoby je bowiem rozumieć jako sposób mówienia: (1a) o jakiejś dziedzinie, (1b) jednej osoby lub (2) wyjątkowy, szczególny, niestandardowy, niekonwencjonalny. Omawiane pojęcie mogłoby więc obejmować swym zakresem rozmaite warianty języka: (1b) idiolekt, (2) styl artystyczny, język kaszubski czy żargon więzienny, wreszcie (1a) styl naukowy lub kody używane w komunikacji zawodowej. Tak rozległa i rozmyta zarazem denotacja świadczy natomiast o poważnej nieścisłości i tym samym dyskwalifikowałaby omawiane wyrażenie jako termin.

Bardziej precyzyjnie można zdefiniować przymiotniki fachowy, profesjonalny, specjalistyczny i zawodowy. Formy te uznawane są przez leksykografów za synonimiczne, choć trzeba wyraźnie zaznaczyć, że nie są one równoznaczne. Najbliższe znaczeniowo są polisemiczne adjektywy fachowy i zawodowy, gdyż sygnalizują m.in., że $x$ jest 'związany z jakimś zawodem'. Słowo specjalistyczny natomiast - ex definitione - 'dotyczy specjalisty', czyli osoby 'odznaczającej się gruntowną znajomością jakiejś dziedziny', przy czym dziedzina jest 'obszar czyjegoś działania w obrębie nauki, gospodarki, techniki, kultury itp.' Z kolei słowo profesjonalny rozumie się wielorako, przy czym znaczenia mogące dookreślać rzeczownik język to: (1) 'będący na wysokim poziomie w danej dziedzinie'; (2) 'spełniający wymagania profesjonalistów'; (3) 'traktowany, uprawiany jako zawód'.

Interpretacja przywołanych objaśnień funkcjonujących w słowniku języka polskiego (Dubisz (red.) 2003) pozwala stwierdzić, że wśród zespoleń język fachowy, język specjalistyczny, język zawodowy i język profesjonalny najmniej wyraziste znaczeniowo jest ostatnie $\mathrm{z}$ nich. Wysoki poziom czy spełnianie wymagań specjalistów nie stanowią dystynktywnych kryteriów czy parametrów umożliwiających identyfikację konkretnego wariantu języka określanego wspomnianym wyrażeniem. $Z$ kolei w odniesieniu do pozostałych trzech połączeń wyrazowych należałoby zwrócić uwagę z jednej strony na tożsamość znaczeniową sformułowań język fachowy oraz język zawodowy odnoszących się do kodu werbalnego używanego w jakimś środowisku zawodowym, a z drugiej na szerszy zakres pojęcia JĘZYK SPECJALISTYCZNY, które odnosiłoby się nie tylko do na-

\footnotetext{
${ }^{3}$ Większość definicji zamieszczonych w tej części tekstu przytaczam za: Dubisz (red.) 2003. Objaśnienia zaczerpnięte z innych źródeł zostały oznaczone w tekście głównym stosownym odwołaniem.
} 
rzędzia komunikacji interpersonalnej w przestrzeni zawodowej (szeroko ujmowana działalność gospodarcza), ale też naukowej czy technicznej.

W przypadku pozostałych dwóch terminów — profesjolekt oraz technolekt — nietożsamość semantyczna warunkowana jest brakiem odpowiedniości znaczeniowej członów inicjalnych. Pierwszy rzeczownik to forma zapożyczona ${ }^{4}$, mająca jednak w swojej budowie człon profesjo- stanowiący podstawę polisemicznego słowa profesja oznaczającego 'zawód'. Taki kontekst leksykalny podpowiada, że wyraz profesjolekt należałoby traktować jako synonim dokładny wyrażeń język zawodowy i język fachowy. Można oczywiście dodatkowo zwrócić w tym miejscu uwagę, że wspomniana cząstka jest także składnikiem przymiotnika profesjonalny, co implikowałoby zgoła inną interpretację, wyłuszczoną w poprzednim akapicie. Wydaje się jednak, że terminy z członem -lekt konstruowane są najczęściej wskutek połączenia z rzeczownikami, nie zaś z adjektywami (np. nacja + -lekt $\rightarrow$ nacjolekt, region + -lekt $\rightarrow$ regiolekt, familia + -lekt $\rightarrow$ familiolekt, gender + -lekt $\rightarrow$ genderlekt). W drugim omawianym wyrazie natomiast komponent techno- to prefiks o rodowodzie greckim sygnalizujący związek z techniką ${ }^{5}$ (Dubisz (red.) 2003 [4]: 36). W takim ujęciu zatem technolekt byłby rodzajem języka specjalistycznego i dlatego obok niego funkcjonowałyby również profesjolekty oraz — zgodnie z przytoczoną powyżej definicją — warianty języka związane z różnymi dziedzinami nauki lub kultury. Trzeba przy tym nadmienić, że o ile dotychczas nie pojawiła się na polskim gruncie nazwa *naukolekt, o tyle leksem kulturolekt ukuty przez Małgorzatę Marcjanik (2008: 71) funkcjonuje w obiegu (co prawda w mocno ograniczonym zakresie). Odnosi się on jednak - jak pisze badaczka - do kodów grzeczności i tym samym nie mieści się w zakresie pojęcia JĘZYK SPECJALISTYCZNY.

Ustalenia poczynione w tej części artykułu klarownie podsumuje porządkujący diagram (ryc. 1), na którym zaznaczono wyabstrahowane z analizowanych definicji zakresy poszczególnych pojęć. Kłopotliwe jest jedynie właściwe usytuowanie JĘZYKA PROFESJONALNEGO (co zasygnalizowano linią przerywaną i pytajnikiem umieszczonym przy nazwie) z uwagi na wykazaną powyżej nieostrość. Wydaje się jednak, że dwa aspekty, tj. spełnianie wymagań profesjonalistów i wysoki poziom, pozwalają uznać to pojęcie za sZersze od JĘZYKA SPECJALISTYCZNEGO, gdyż aprobata specjalistów może zostać skierowana nie tylko na warianty używane w środowisku naukowym czy zawodowym. Z kolei JĘZYK SPECJALNY — jak wynika $z$ analiz — ma najszerszy zakres, bowiem może obejmować różnorakie odmiany — od idiolektu poczynając, poprzez dialekty czy żargony, na stylach kończąc.

${ }^{4}$ Szczegółowe informacje na ten temat znajdują się w przedostatniej części artykułu.

${ }^{5}$ Waldemar Żarski (2008: 154) sugeruje, że w interpretacji terminu technolekt pojęcie TECHNIKI należy rozumieć nie jako 'dziedzinę działalności związaną z wytwórczością przedmiotów nieistniejących w środowisku naturalnym', a jako 'sposób wykonywania określonych czynności; metodę'. Wydaje się jednak, że takie ujęcie jest nieadekwatne, wszak omawiany typ lektu odnosi się do działalności i wytwórczości, nie zaś do metod działania. Sposoby wykonywania czynności mogą być bowiem powtarzalne w różnych dziedzinach (np. w inżynierii, mechanice i architekturze). 


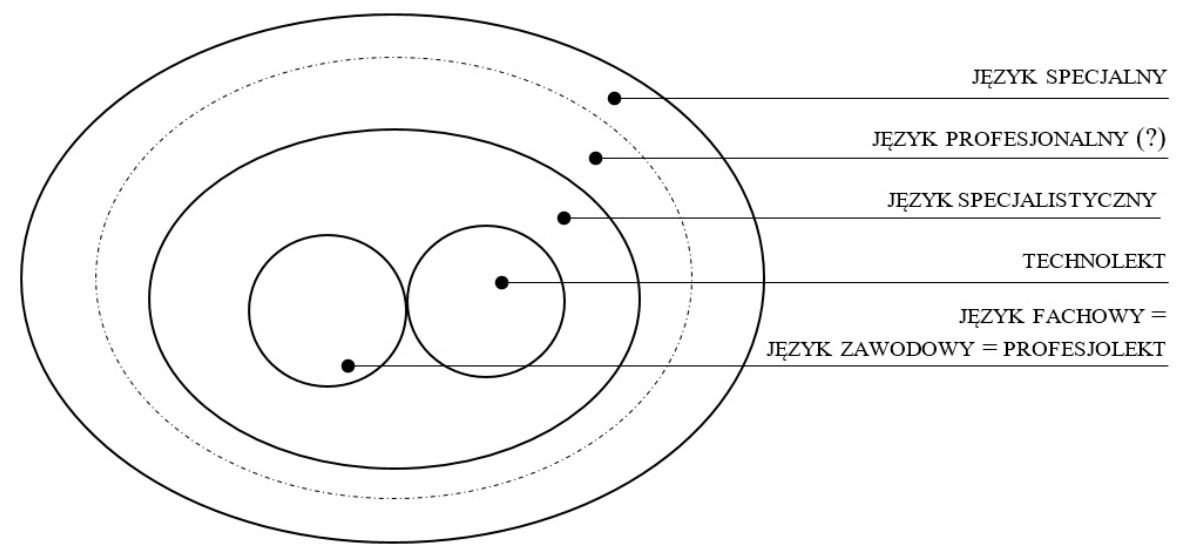

Ryc. 1. Zakresy badanych pojęć (na podstawie analizy leksykalnej).

Źródło: opracowanie własne.

\section{Analiza leksykonów terminologicznych}

Kolejny etap badań stanowi analiza objaśnień zawartych w słownikach zawierających terminologię lingwistyczną i już na wstępie trzeba zaznaczyć, że nie udało się odnaleźć w tego typu publikacjach żadnych wzmianek o jednej z badanych nazw — profesjolekt. Pozostałe formy zostały uwzględnione w objętych kwerendą zbiorach jako samodzielne hasła bądź pojawiały się w obrębie definiensów innych terminów.

Znaczenie jednego z analizowanych wyrażeń — język specjalny — przybliżono blisko pół wieku temu w „Słowniku terminologii językoznawczej”, przyjmując, że jest to ,język grupy społecznej znajdującej się w stosunku do całości społeczeństwa z takiego lub innego względu w szczególnych warunkach” i chodzi tutaj o wspólnoty ,zawodowe lub środowiskowe (np. sądowników, lekarzy, [...] uczniów [...] itd.), często wartościowane ujemnie (przestępcy, złodzieje) lub dodatnio (inteligencja)" (Gołąb, Heinz, Polański 1970: 527)6 Tak skonstruowane objaśnienie pozwala ujmować omawianą nazwę jako semantyczny odpowiednik terminu socjolekt definiowanego obecnie w literaturze lingwistycznej w niemal identyczny sposób (zob. np. Wilkoń [1987] 2000: 88 i n.; Grabias [1994] 2003: 139).

Podobna definicja sformułowania język specjalny funkcjonuje również w „Encyklopedii językoznawstwa ogólnego”, gdzie przyjęto, że jest ono synonimiczne względem zespolenia język środowiskowy i odnosi się do wariantów używanych w grupach społecznych ,wyodrębniających się z ogółu społeczeństwa albo pod względem wieku (jęz. młodzieżowy, uczniowski), albo [...] wykonywanego zawodu (jęz. lekarzy, prawników itp.), albo [...] rodzaju działalności (jęz. złodziei)" (Polański (red.) [1993] 2003:

${ }^{6}$ Trzeba dodać, że w tym zbiorze wskazano semantyczne odpowiedniki terminu funkcjonujące w języku angielskim (vocational slang), francuskim (langue spéciale), niemieckim (Sondersprache) i rosyjskim (specjalnij jazyk), a także podano inne nazwy stosowane w odniesieniu do kodów używanych w grupach społecznych (fr. argot, jargon, ang. slang, cant, niem. Rotwelsch, pol. gwara, wiech) (Gołąb, Heinz, Polański 1970: 527). 
273). Pamiętając zatem o nieostrości przymiotnika specjalny i wykazanej w poprzedniej części tekstu możliwości odnoszenia omawianej nazwy zarówno do idiolektów, jak i do stylów czy gwar, należy podkreślić utrwalone w przywołanych leksykonach (i typowe dla tego typu publikacji) istotne zawężenie znaczenia. Trzeba także dodać, że autorzy obu zbiorów zamieścili w przywołanych tu hasłach informację, że kod specjalny odróżnia od języka ogólnego jedynie słownictwo, przy czym nie sprecyzowano, czy chodzi o formy terminologiczne, neutralne czy też ekspresywne.

Wyrażenie język specjalistyczny również udało się odnaleźć w dwóch zbiorach leksykograficznych wydanych na przestrzeni kilku dekad. Pierwszym leksykonem jest „Podręczny słownik językoznawstwa stosowanego”, w którym wspomnianą nazwę uznano za równoznacznik zespolenia język fachowy (zasygnalizowano ów fakt matematycznym znakiem równości) ${ }^{7}$, przypisując jej następującą definicję: „,szczególna postać języka ogólnonarodowego przystosowana do możliwie precyzyjnego opisu określonej gałęzi wiedzy lub techniki" (Szulc 1984: 106-107). Stwierdzono ponadto, że odrębność desygnowanego kodu od języka ogólnego sprowadza się głównie do obecności leksyki fachowej, zawierającej często internacjonalizmy, oraz do wyższej frekwencji określonych form gramatycznych. Za parametr odróżniający uznano również składnię, jednak nie sprecyzowano, w czym owa odmienność miałaby się przejawiać. Tak skonstruowane objaśnienie może sugerować tożsamość pojęć JĘZYK SPECJALISTYCZNY, JĘZYK FACHOWY, JĘZYK ZAWODOWY, choć eksplicytnie nie stwierdzono w tym przypadku zamienności zakresów. W dodatku w tym samym słowniku w haśle socjolekty zanotowano, że rzeczownikiem tym można nazwać m.in. „«żargon» lub któryś z języków określanych jako «zawodowe»" (Szulc 1984: 216). Na podstawie utrwalonych w leksykonie objaśnień można zatem sformułować kilka wniosków/hipotez: $\left(\mathrm{W}_{1}\right)$ forma język zawodowy na początku lat 80 . XX w. nie miała charakteru terminologicznego; $\left(\mathrm{W}_{2}\right)$ JĘZYK SPECJALISTYCZNY i JĘZYK ZAWODOWY to pojęcia nietożsame, gdyż pierwsze z nich odnosi się do komunikacji na temat jakiejś dziedziny nauki lub techniki, drugie zaś - do porozumiewania się w środowiskach zawodowych; $\left(\mathrm{W}_{3}\right)$ skoro terminy język specjalistyczny i język fachowy są synonimiczne, to na podstawie $\mathrm{W}_{2}$ należy uznać, że zakresy pojęć JĘZYK FACHOWY i JĘZYK ZAWODOWY nie są zamienne.

Wyrażenie język specjalistyczny zdefiniowano także w stosunkowo nowym słowniku pod redakcją Jerzego Lukszyna ([2002] 2005). W leksykonie tym przyjęto, że omawiany termin desygnuje kod używany „,w komunikacji zawodowej do porozumiewania się tylko w odniesieniu do określonych tematów specjalistycznych" (Lukszyn (red.) [2002] 2005: 40), co oznacza, że należy traktować omawiane zespolenie jako synonimiczne względem sformułowania język zawodowy. W leksykonie nazwę język specjalistyczny usytuowano ponadto w bliskim otoczeniu terminologicznym, przyjmując, że jest ona: (1) hiperonimiczna względem wyrażeń język naukowy oraz język techniczny; (2) przeciwstawna wobec połączenia wyrazowego język ogólny; (3) równoznaczna z formami

${ }^{7}$ Aleksander Szulc (1984: 106) wynotował także obcojęzyczne ekwiwalenty terminu: ang. scientific/ technical language, special language, fr. (la) langue de spécialité, (la) langue scientifique, niem. (die) Fachsprache, ros. techničeskij jazyk (por. Pajewska 2003; Grucza S. 2008). 
technolekt oraz język zawodowy; (4) bliskoznaczna z zespoleniem język fachowy; (5) stowarzyszona $\mathrm{z}$ terminem argot profesjonalny. Niestety w omawianej publikacji nie objaśniono nazw technolekt, język fachowy i język zawodowy zapewne ze względu na uznawaną zbieżność lub tożsamość znaczeniową. Wskutek pominięcia definicji nie wiadomo jednak, jakie parametry odróżniająjęzyk specjalistyczny od języka fachowego ani do czego sprowadza się zasadnicza odrębność między językiem technicznym a technolektem. Brak szczegółowych charakterystyk jest szczególnie dotkliwy w odniesieniu do dwóch ostatnich form, które - jak wspomniano - autorzy słownika umieścili na różnych poziomach — jedną z nich uznano bowiem za hiponim, drugą zaś za formę równorzędną.

W „Małym słowniku terminów z zakresu socjolingwistyki i pragmatyki językowej” funkcjonuje z kolei wyrażenie język zawodowy uznawane za nazwę określającą ,typ socjolektu, środowiskowej odmiany języka [...], [który] funkcjonuje w grupie społecznej związanej z działalnością zawodową i służy codziennej komunikacji na tematy zawodowe" (Skudrzykowa, Urban 2000: 81). Dodatkowo wspomniano, że do tego typu kodów odnosi się również sformułowanie język profesjonalny, a leksyka w wariantach desygnowanych obiema nazwami służy ścisłemu przekazywaniu myśli. Na podstawie przywołanych informacji należałoby zatem uznać, że pojęcia JĘZYK ZAWODOWY i JĘZYK PROFESJONALNY są zakresowo zamienne i mieszczą się w obrębie pola semantycznego SOCJOLEKT.

Warto jeszcze wspomnieć o trzech istotnych kwestiach. Po pierwsze: $\mathrm{w}$ „Tezaurusie terminologii translatorycznej” nazwę język fachowy zanotowano w obrębie hasła język tekstów specjalistycznych jako termin semantycznie powiązany. Nie określono jednak dokładnie charakteru relacji łączącej oba wyrażenia. W dodatku zdefiniowano jedynie to drugie zespolenie, przyjmując, że jest to „funkcjonalna odmiana języka narodowego charakteryzująca się przede wszystkim odrębnością leksykalno-frazeologiczną" (Lukszyn (red.) 1993: 143). Biorąc pod uwagę wysoki stopień ogólności objaśnienia, trudno jednoznacznie stwierdzić, czym w zamyśle leksykografów faktycznie charakteryzuje się ów wariant języka. Po drugie: w „Słowniku kluczowych pojęć językoznawstwa slawistycznego" wymieniono jedynie dwa interesujące mnie terminy: język specjalistyczny i język zawodowy (Rudnik-Karwatowa, Karpińska 1999: 53-54). Niestety w zbiorze tym przywołane nazwy jedynie zanotowano i nie podano definicji, jednak wskazanie akurat tych form może sugerować ich typowość, wysoką frekwencję w dyskursie lingwistycznym albo świadczyć o braku pozostałych omawianych tu sformułowań w systemie nazewniczym końca XX wieku. Po trzecie wreszcie: zbiór informacji utrwalonych w przywołanych słownikach może stanowić istotną wskazówkę w badaniach dziejów poszczególnych terminów na polskim gruncie.

Analizując zatem zawartość dzieł leksykograficznych gromadzących terminologię językoznawczą, należy przede wszystkim zwrócić uwagę na nieobecność nazwy profesjolekt. Fakt ten jest dość zastanawiający, jeśli weźmiemy pod uwagę, że forma ta funkcjonuje w polskim piśmiennictwie od kilku dekad — Aleksander Wilkoń ([1987] 2000) wprowadził ją bowiem już w latach 80 . ubiegłego wieku. W skompletowanych leksykonach zdefiniowano właściwie trzy terminy - język specjalny, język specjalistyczny oraz język zawodowy, pozostałe rzeczowniki i zespolenia (technolekt, język 
fachowy, język profesjonalny) pojawiają się natomiast sporadycznie w objaśnieniach wymienionych sformułowań lub w innych hasłach (typu socjolekt czy język tekstów specjalistycznych). Konfrontacja odnalezionych definicji obrazuje niejednomyślność badaczy w określaniu zakresów nazw i wyznaczaniu relacji pomiędzy nimi. Ogólnie rzecz ujmując, należałoby stwierdzić identyfikowalną odrębność pojęć JĘZYK SPECJALNY i JĘZYK SPECJALISTYCZNY. Pierwsze z nich odnosi się do wariantów, którymi operują różne grupy społeczne (tzn. do socjolektów), drugie zaś denotuje kody służące precyzyjnej nominacji zjawisk w sferze nauki i techniki. W dwóch słownikach wskazano eksplicytnie lub zasugerowano związki znaczeniowe wyrażenia język specjalistyczny z innymi nazwami. Trzeba jednak wyraźnie podkreślić dwojakie postrzeganie relacji łączącej wspomniane zespolenie z terminem jezzyk zawodowy: w nowszej publikacji poinformowano o tożsamości semantycznej, w starszej zaś obie formy umieszczono w obrębie różnych haseł i nie stwierdzono zbieżności czy styczności pojęć, co należałoby interpretować jako poświadczenie ich odrębności. Z kolei w słowniku Aldony Skudrzykowej i Krystyny Urban język zawodowy stanowi równoznacznik zespolenia język profesjonalny.

Najlepszym podsumowaniem poczynionych ustaleń będzie kolejny diagram (ryc. 2), który klarownie zilustruje sygnalizowane w leksykonach relacje między zakresami poszczególnych nazw. Dodam przy tym, że w skonstruowanym schemacie nie zostały uwzględnione formy język środowiskowy, język naukowy, język techniczny, język ogólny, argot profesjonalny i język tekstów specjalistycznych, ponieważ nie mieszczą się one w granicach określonych celem niniejszego tekstu. Wyjątek uczyniono względem rzeczownika socjolekt, który stanowi wyraźnie wskazywany, istotny kontekst terminologiczny i pojawi się w dodatku w dalszych analizach.
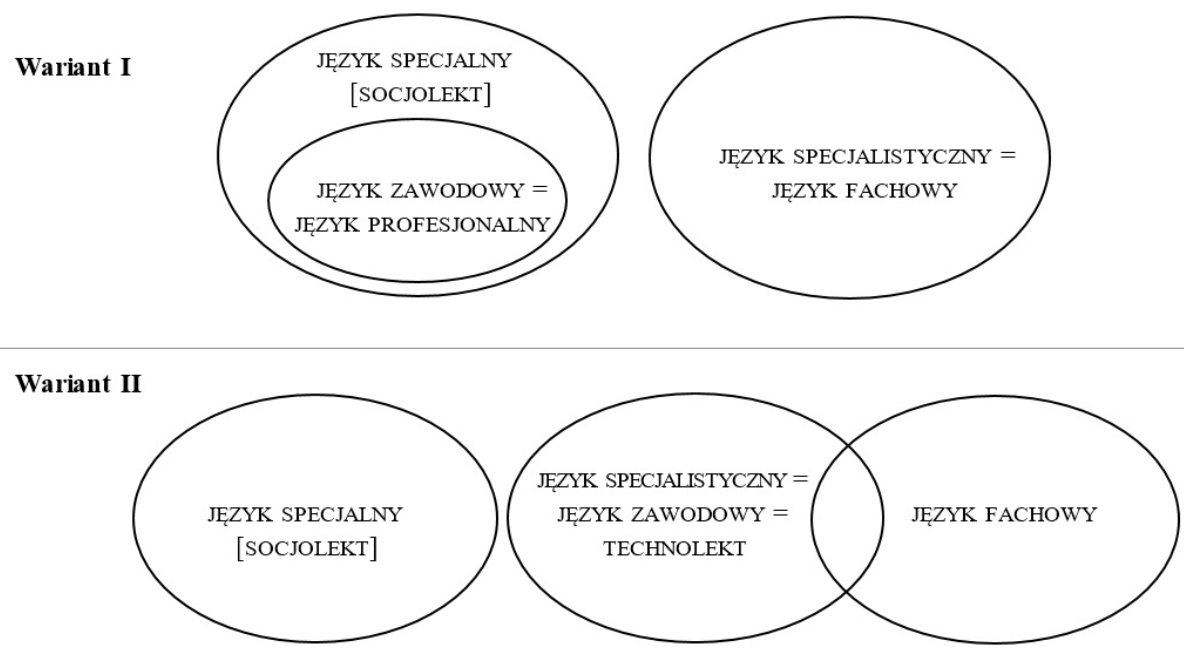

Ryc. 2. Zakresy badanych pojęć (na podstawie analizy objaśnień leksykograficznych: wariant I — Gołąb, Heinz, Polański 1970; Polański (red.) 1993; Szulc 1984; Skudrzykowa, Urban 2000; wariant II — Gołąb, Heinz, Polański 1970; Polański (red.) 1993; Lukszyn [2002] 2005).

Źródło: opracowanie własne. 


\section{Analiza opracowań lingwistycznych}

Interpretacji ostatniej grupy źródeł należy dokonać, biorąc pod uwagę (1) użycie omawianych terminów w rozważaniach językoznawczych oraz (2) teoretyczne propozycje definiowania i rozgraniczania pojęć, przy czym analizę wypada rozpocząć od wskazania kilku niepokojących tendencji w konstruowaniu lingwistycznego wywodu. Po pierwsze: w literaturze łatwo można natrafić na wyliczenia interesujących mnie nazw pozbawione objaśniającego czy porządkującego komentarza (por. Grucza S. [2004] 2013: 21). Po drugie: badacze, operując wybraną formą, chętnie umieszczają w towarzyszącym jej nawiasie kolejne sformułowania (np. język specjalistyczny (technolekt, język zawodowy, język profesjonalny); Sawicka A. 2009) lub wpisują je po ukośniku (np. język zawodowy / język profesjonalny / język specjalistyczny; Pajewska 2003), co sugeruje synonimiczność czy wręcz tożsamość znaczeń. Po trzecie: zdarzają się przypadki wyraźnego utożsamiania pojęć poprzez mechaniczne przypisanie definicji nazwy x wyrażeniu y. W jednym z artykułów sformułowano bowiem stwierdzenie, że dotychczas ,zaproponowano wiele definicji języka specjalistycznego [...]; [p]rzykładowo, w Słowniku terminologii językoznawczej [...], przy czym [...] jego autorzy używają określenia język specjalny, a nie specjalistyczny" (Gonigroszek 2017: 186). Przywołane sposoby budowania narracji świadczą bez wątpienia o istnieniu poważnego problemu terminologicznego, którego rozległość pozwoli określić wnikliwa analiza polskojęzycznych opracowań lingwistycznych. Nie sposób oczywiście uwzględnić wszystkich propozycji zawartych w licznych pracach, dlatego przywołuję poniżej wybrane ujęcia reprezentujące ugruntowane, powszechnie podzielane, bądź - rzadziej — oryginalne, indywidualne koncepcje rozmaitych badaczy.

W dostępnej literaturze przedmiotu zgodnie przyjmuje się, że formy język specjalistyczny i technolekt są wariantywne, określające ten sam desygnat (np. Grucza F. 1991; 1994; 2002; Szadyko 2013; Lesicka 2015). W jednym z opracowań - co ciekawe wyrażenie języki specjalistyczne obudowano komentarzem tak zwane (Gonigroszek 2017: 186), co sugeruje, że jest ono z jakichś powodów nieadekwatne lub nie stanowi ustabilizowanego składnika polskiego systemu terminologicznego. Obserwacja publikacji z ostatniego trzydziestolecia i kilku prac wcześniejszych pozwala jednak uznać, że taki sposób zapisu/opisu jest odosobniony. Łatwo natomiast dostrzec sygnalizowaną przez Stanisława Gajdę (1997: 7) nieostrość zakresu tej nazwy.

Z jednej strony kody nazywane językami specjalistycznymi łączy się z dyscyplinami nauki lub/i z rozmaitymi sferami techniki (np. Grucza S. 2008), podając jako przykłady ,język bankowości, język giełdowy, język prawa międzynarodowego, język prawa karnego, język informatyki, budownictwa, ciepłownictwa itd." (Hejwowski 2001: 178). Takie ujęcie potwierdzałoby zatem (choć tylko połowicznie) konstatację Jana Lewandowskiego (2002: 28), który stwierdził, że najpełniejszej charakterystyki fenomenu zwanego dziś językiem specjalistycznym dokonał w latach 80 . XX w. Stanisław Gajda (1982) posługujący się wówczas terminem język naukowy. Świadczyłoby to zatem o równoznaczności obu wyrażeń, przy czym — zgodnie z przywołaną powyżej 
koncepcją — z nazwąjęzyk specjalistyczny należałoby również wiązać zespolenie język techniczny. Czyni tak zresztą Rajmund Ohly (2002: 50), który JęZYK TECHNICZNY uznał za pojęcie podrzędne względem JĘZYKA SPECJALISTYCZNEGO.

$\mathrm{Z}$ drugiej strony lingwiści konstatują, że „swoje języki specjalistyczne mają nie tylko różne dziedziny techniczne i/lub naukowe, lecz w gruncie rzeczy wszystkie dziedziny ludzkiej działalności (twórczości) wykonywanej zawodowo" (Grucza F. 2002: 11, 13). Tak sformułowana charakterystyka odbiega oczywiście od opisanego powyżej ujęcia za sprawą uznania za języki specjalistyczne kodów, którymi operują grupy „ludzi zajmujących (trudniących) się jakimś (mniej lub bardziej dokładnie) określonym rodzajem pracy" (ibidem: 18-19), np. wytwórcy porcelany lub myśliwi (Grygoruk 2009: 62).

Przywołane koncepcje implikują zatem dwie perspektywy oglądu JĘZYKÓw SPECJALISTYCZNYCH: (1) pozasocjolektalną i (2) socjolektalną. W pierwszym przypadku omawiane kody postrzegane są jako autonomiczne względem socjolektów, co bywa stwierdzane expressis verbis (Pytel 2004: 102; Grucza S. 2008: passim) lub też wynika z pomijania milczeniem ewentualnego związku z odmianami używanymi w grupach społecznych. W drugim przypadku natomiast języki specjalistyczne uznaje się za rodzaj socjolektu wskutek przyjęcia, że konstruują je i operują nimi ludzie zajmujący się konkretną działalnością techniczną lub naukową albo wykonujący określony zawód ${ }^{8}$ (np. Grucza F. 2002: 19; Grygoruk 2009: 62). Trzeba jednak wyraźnie podkreślić, że w żadnej znanej mi typologii społecznych odmian języka nie użyto dotychczas ani nazwy język specjalistyczny (por. Jarosz 2016), ani wariantywnego rzeczownika technolekt, który w jednym z opracowań uznano za hiponim socjolingwistycznego terminu socjolekt (Gajewska, Sowa 2014: 19).

Warto w tym kontekście przywołać stanowisko Bronisławy Ligary (2011), która utożsamia JĘZYKI SPECJALISTYCZNE z PROFESJOLEKTAMI, jednak sytuowanie tych fenomenów w obrębie socjolektów uważa za nieuprawnione. Zestawia się bowiem jej zdaniem kody „młodzieżowy oraz złodziejski, a z drugiej strony — język osób wykonujących dany zawód, abstrahując tym samym całkowicie od faktu, że te dwa typy języków różnią się zasadniczo prag m a ty c zn y $\mathrm{m}$ celem ich powstania, a następnie używania" (Ligara 2011: 164; wyróżnienie oryginalne). Taka argumentacja może się jednak wydawać dyskusyjna. O ile bowiem prymarną przyczyną konstruowania slangów (studenckiego, uczniowskiego czy hiphopowego) jest ekspresja, o tyle żargony (złodziejski czy więzienny), podobnie jak odmiany zawodowe, mają w zamyśle użytkow-

\footnotetext{
${ }^{8}$ Ponadto w obręb SOCJOLEKTÓw wprowadzają JĘZYK SPECJALISTYCZNY objaśnienia informujące, że, jest to swego rodzaju żargon, którym na co dzień posługują się użytkownicy specjalizujący się w danej dziedzinie" (Trzaskawka 2014: 58). Trzeba jednak podkreślić, że w przywołanym ujęciu rzeczownik żargon używany jest w sposób intuicyjny, potoczny, a zatem w nieuprawniony sposób oderwany od naukowego kontekstu. Nazwa ta ma bowiem na gruncie socjolingwistycznym ściśle określone znaczenie — desygnuje ona kody intencjonalnie tajne stanowiące narzędzie komunikacji w grupach izolujących się od społeczeństwa, kontestujących, zwykle wiązanych z nieaprobowanymi powszechnie działaniami lub zachowaniami (np. więźniowie, narkomani, prostytutki) (Grabias 1974; [1994] 2003; Piekot 2008; por. Jarosz 2016).
} 
ników realizować przede wszystkim — jak określił to Stanisław Grabias (1974) — funkcje profesjonalno-komunikatywne. Budowane są zatem również w celach pragmatycznych, stąd separowanie profesjolektów i socjolektów nie jest moim zdaniem dostatecznie umotywowane ${ }^{9}$. Trudno też odnieść się do argumentu, że ,profesjolekty w stosunku do pozostałych socjolektów obsługują różne obszary rzeczywistości" (Ligara 2011: 165), ponieważ badaczka nie rozwija przywołanej tezy. Ważne jest jednak, że w omawianym artykule postawiono znak równości między pojęciami JĘZYK SPECJALISTYCZNY i PROFESJOLEKT, JĘZYK SPECJALISTYCZNY i JĘZYK ZAWODOWY, a takŻe JĘZYK SPECJALNY i SOCJOLEKT (ibidem: 168-169), wyraźnie oddzielając w ten sposób JĘZYK SPECJALISTYCZNY i JĘZYK SPECJALNY.

Przywołana nazwa profesjolekt jest właściwie powszechnie wiązana z terminem socjolekt, przy czym jest traktowana jako forma albo podrzędna, albo równorzędna, a zatem odrębna zakresowo. Taka niejednomyślność ma swoje źródło w sformułowanej w latach 80. XX w. koncepcji Aleksandra Wilkonia ([1987] 2000: 87 i n.). Lingwista odróżnił bowiem odmiany socjalne (socjolekty) od zawodowych (profesjolekty), przyjmując, że pierwsze z nich funkcjonują w określonych grupach społecznych i stanowią istotny ich wyróżnik, drugie zaś są narzędziami porozumienia w środowiskach zawodowych i cechują się jedynie obecnością słownictwa specjalnego (odmianki fachowe). Co ważne, badacz w wydzielonych z kolei typach socjolektów usytuował kody używane w zbiorowościach połączonych konkretną profesją (np. górników, żołnierzy, marynarzy), biorąc najwyraźniej pod uwagę, że wykształcone w tych wspólnotach warianty spajają jej członków i odzwierciedlają określony sposób postrzegania świata. Okazuje się zatem, że instrumenty służące komunikowaniu się w środowiskach zawodowych mogą przynależeć do obu wyróżnionych kategorii odmian języka. Współcześnie natomiast raczej powszechnie traktuje się profesjolekt jako typ socjolektu, zasadnie argumentując, że zarówno wspólnoty rówieśnicze oraz kontestujące, jak i zespoły osób wykonujących tę samą pracę stanowią rodzaje grup społecznych (np. Grabias 1974; [1994] 2003; Sawicka G. 2006; Piekot 2008; Kołodziejek 2010; por. Jarosz 2016). W polskiej literaturze lingwistycznej można jednak sporadycznie odnaleźć inne stanowiska. Odosobniony jest m.in. głos Aleksandra Kiklewicza (2009: 70), który uznał, że parametry cechujące profesjolekty — tj. językowe wykładniki zawodowości - przemawiają za wyodrębnieniem tych kodów ze zbioru socjolektów i usytuowaniem ich zarazem w obrębie stylów. Innym nietypowym ujęciem jest utożsamienie PROFESJOLEKTU z IDIOLEKTEM SPECJALISTYCZNYM (Gajewska, Sowa 2014: 43), czyli — zgodnie z objaśnieniem Franciszka Gruczy (1993: 159) i Sambora Gruczy (np. 2010: 50; [2004] 2013: 28) $-\mathrm{z}$ językiem jedynie konkretnej (pojedynczej) osoby, co eliminuje tym samym fundamentalną dla socjolingwistów perspektywę grupową.

\footnotetext{
${ }^{9}$ Nie wiadomo również, do jakiego typu kodów należałoby przyporządkować JĘZYKI SPECJALISTYCZNE || PROFESJOLEKTY, skoro — zgodnie z przywoływanym ujęciem badaczki — powinny one zostać wyłączone z grupy SOCJOLEKTów. Nie są to z pewnością zjawiska zogniskowane terytorialnie jak dialekty, jednak nie zostało określone, czy należy je sytuować w obrębie innych rodzajów odmian, np. stylów (por. Kiklewicz 2009: 70) czy raczej ujmować jako kody swoiste, autonomiczne (por. np. Grucza S. 2013: 27).
} 
W opracowaniach analitycznych można w dodatku zaobserwować wyraźną niestety tendencję do wymiennego stosowania terminów profesjolekt i socjolekt, o czym świadczy fakt określania tym drugim rzeczownikiem kodów używanych przez paralotniarzy, kierowców, alpinistów czy biegaczy (Pędzich 2012; Jaros 2013; Niepytalska-Osiecka 2014; Kijak 2015). Takie postępowanie może być pochodną pozornej niekonsekwencji obecnej w ujęciu Aleksandra Wilkonia, ale może też wynikać z przyjmowania postawy asekuracyjnej, bowiem nie natrafiłam dotychczas na pracę, w której zostałaby wykazana tożsamość semantyczna obu terminów. Niektórzy (nie tylko początkujący) lingwiści w dyskusjach podczas konferencji naukowych stwierdzają w dodatku, że uświadamiają sobie ogólność nazwy socjolekt obejmującej swym zakresem slangi, żargony i profesjolekty, jednak używają jej, ponieważ się do niej przyzwyczaili10. Trzeba też odnotować, że niektórzy badacze wyraźnie traktują również formy socjolekt i język specjalistyczny jako równoznaczne, co w świetle powyższych analiz nie jest uzasadnione żadnymi argumentami (Kryżan-Stanojević, Sychowska-Kavedžija 1996: 55; Godzich 2014: 124). Być może jednak operowanie tym rzeczownikiem jest pochodną sygnalizowanych chociażby przez Ewę Pajewską (2003: 26) problemów definicyjnych związanych z terminem profesjolekt. W oparciu o koncepcje czeskie i słowackie lingwistka zwraca bowiem uwagę, że profesjolektem nie należy określać chociażby kodu wędkarskiego czy łowieckiego, gdyż posługują się nimi osoby, których nie łączy zawód wykonywany w celach zarobkowych, a jedynie hobby ${ }^{11}$ (por. Tokarski 1977: 121). Wypada jednak zaznaczyć, że zarówno myślistwo, jak i wędkarstwo stanowią formy aktywności, które wymagają przyswojenia określonej wiedzy oraz wypracowania konkretnych umiejętności. Z tego też względu kojarzenie tych zajęć z profesjonalizmem wydaje się naturalne i uzasadnione i choć oczywiście prymarnie nie mają one związku z pozyskiwaniem pieniędzy, to aspekt ten nie jest wykluczony (weźmy chociażby pod uwagę sprzedaż mięsa upolowanej zwierzyny czy złowionych ryb). Wydaje się zatem, że PROFESJĘ należałoby w tym przypadku rozumieć szerzej, zwłaszcza że przestarzałe dziś wyrażenie z profesji oznaczało 'zawodowo, z nawyku, z upodobania, stale' (por. Doroszewski 1965). Pamiętajmy zresztą, że rzeczownik profesjolekt nie powstał na polskim gruncie, o czym świadczy fakt, że już w latach 70. XX w. posłużył się nim w angielskim tekście duński lingwista Peder Skyum-Nielsen (1978: 1). Współcześnie natomiast leksem profession (ang.) oznacza zarówno 'zawód', jak i ‘środowisko (np. lekarzy, myśliwych), grupę zawodową'. Zwłaszcza ta ostatnia uwaga uprawnia dostatecznie jak sądzę - objęcie nazwą profesjolekt kodów konstruowanych nie tylko w kręgach wyodrębnionych ze względu na wykonywany zawód, ale też w zbiorowościach zajmujących się wprawdzie nie zawodowo, ale profesjonalnie jakąś formą aktywności, np. wspinaczką górską czy kulturystyką (por. Kiklewicz 2007: 23).

\footnotetext{
${ }^{10}$ Wyznanie takich preferencji pojawiło się m.in. w spisanej dyskusji panelowej, którą można odnaleźć $\mathrm{w}$ jednym $\mathrm{z}$ tomów wynotowanych w bibliografii zamieszczonej pod tekstem.

${ }^{11}$ Trzeba także w tym miejscu dodać, że gdybyśmy mieli bardzo ściśle trzymać się zakresu nazwy PROFESJA, wówczas należałoby uwzględnić kontekst socjologiczny — na gruncie tej dyscypliny naukowej bowiem odróżnia się wspomniane pojęcie od ZAWODU (np. Reduta 2015).
} 
Rozważania teoretyczne oraz badania empiryczne dotyczące narzędzi komunikowania określanych mianem profesjolektów pozwalają stwierdzić, że struktura słownictwa w tych wariantach języka jest złożona, gdyż składa się zarówno z terminologii naukowo-technicznej, jak i z leksyki profesjonalnej obejmującej formy nieścisłe, ekspresywne, okazjonalne (np. Janasowa 1979; Żydek-Bednarczuk 1987; Ożdżyński 1996). Współfunkcjonowanie form nienacechowanych, o sprecyzowanym znaczeniu z określeniami wartościującymi jest jak najbardziej zrozumiałe, jeśli weźmiemy pod uwagę fakt, że spontaniczna, codzienna komunikacja w środowisku zawodowym skłania do emocjonalnego reagowania na zjawiska typowe dla danej profesji (por. Kuć 2011; Dąbkowski 2010). Obecność tych warstw leksyki stanowiłaby natomiast parametr odróżniający PROFESJOLEKTY od JĘZYKÓw SPECJALISTYCZNYCH, w których — jak czytamy w licznych opracowaniach - słownictwem swoistym jest wyłącznie terminologia naukowo-techniczna ${ }^{12}$ (np. Grucza S. 2008; Lukszyn 2009; Ligara 2011; por. Karpiński, Michałowski 2012). Świadczy zresztą o tym uznawanie opracowywania dzieł poświęconych istocie terminologii za początek badań nad językami specjalistycznymi (por. Grucza [2004] 2013). Z tego punktu widzenia zatem określanie mianem języka specjalistycznego kodów używanych przez wspominanych już myśliwych czy wytwórców narzędzi (Grygoruk 2009: 62) powinno budzić uzasadnione wątpliwości.

Współcześnie w literaturze przedmiotu nazwę profesjolekt najczęściej stosuje się wymiennie z wyrażeniem język zawodowy (np. Grabias [1994] 2003; Kuć 2011), a czasem wyraźnie stwierdza się równoznaczność obu form (np. Ligara 2011). Trzeba jednak przy tym pamiętać, że w latach 70. XX w. Andrzej Piotrowski i Marek Ziółkowski (1976) omawiany typ socjolektu określali wyłącznie mianem język zawodowy używanym - co ciekawe - już ponad wiek temu przez Karola Appla (1908: 27-28). W jednej pracy znalazłam natomiast zapis profesjolekt/technolekt mogący oznaczać zamienność zakresów obu nazw (Kiklewicz 2009: 70). W tym samym opracowaniu uznano jednak, że styl techniczny/przemysłowy posiada dwie odmiany: „oficjalną, czyli technolektalną, oraz obiegową, czyli profesjolektalną" (ibidem: 79). Takie objaśnienie wskazuje zatem, że oba rzeczowniki odnoszą się do różnych fenomenów.

Polscy lingwiści chętnie podejmują próby określenia związków semantycznych łączących nazwy język zawodowy i język specjalistyczny. Ewa Pajewska (2003), bazując na definicjach niemieckich form Fachsprache i Beruffsprache, uznaje, że polskie terminy należy ujmować jako — odpowiednio — hiponim i hiperonim. Wyrażenie język zawodowy (= Beruffsprache) uwypukla bowiem — jej zdaniem — ,zawodowość, czyli wykorzystanie posiadanej kompetencji do celów zarobkowych", zespolenie język specjalistyczny (= Fachsprache) zaś — „fachowość rozumian[a] jako kompetencja użyt-

${ }^{12}$ Wydaje się, że takie ujęcie jest rozpowszechnione we współczesnej polskojęzycznej literaturze lingwistycznej, choć chociażby Lothar Hoffman definiował JĘZYKI SPECJALISTYCZNE bardzo szeroko, ujmując ów fenomen jako zbiór wszystkich form używanych w komunikacji w obrębie określonej specjalności (podaję za: Pajewska 2003: 17). 
kowników odnośnie danej dziedziny" (Pajewska 2003: 15, przypis 2). Na tej podstawie badaczka uznaje, że w obrębie JĘZYKA SPECJALISTYCZNEGO należy sytuować kody używane w komunikacji praktycznej (JĘZYKI ZAWODOWE) oraz teoretycznej, prowadzonej na gruncie poszczególnych dyscyplin (JĘZYKI NAUKOWE). Podobnych rozstrzygnięć dokonały Elżbieta Gajewska i Magdalena Sowa (2014: 46), przy czym lingwistki za odmiany JĘZYKÓW SPECJALISTYCZNYCH uZnały JĘZYKI ZAWODOWE oraZ JĘZYKI BRANŻOWE. W polskim piśmiennictwie pojawiają się również inne koncepcje, na podstawie których należałoby inaczej wytyczyć kierunek relacji łączący omawiane nazwy. Stanisław Gajda (1990) w obrębie JĘZYKA (a właściwie STYLU) NAUKOWEGO wyróżnił bowiem m.in. ODMIANĘ PRAKTYCZNONAUKOWĄ stosowaną w procesie produkcyjnym, którą można postrzegać jako odpowiednik wymienionych powyżej JÆ̨ZYKów ZAWODOWYCH. Oznaczałoby to zatem, że JĘZYK ZAWODOWY jest podrzędny względem JĘZYKA NAUKOWEGO ${ }^{13}$. $Z$ kolei Bronisława Ligara przyjmuje, że kryterium pozwalającym części badaczy na wyróżnienie obu fenomenów jest kanał komunikacji - JĘZYK ZAWODOWY uznaje się za prymarnie mówiony (np. język lekarzy), JĘZYK NAUKOWY zaś ujmuje się jako realizowany głównie w tekstach pisanych (np. język medycyny). Takie rozróżnienie jest jednak zdaniem lingwistki nieuzasadnione, gdyż „oba typy języka obsługują ten sam segment rzeczywistości pozajęzykowej objęty przez daną dziedzinę specjalistyczną" (Ligara 2011: 165). Na tej podstawie termin język specjalistyczny uznaje za bardziej adekwatny i zaznacza przy tym za Marią Teresą Camré, że „specjalistyczność” jest cechą stopniowalną, co pozwala na odniesienie nazwy do różnych przejawów ludzkiej działalności (chemia, geologia > bankowość, handel > fryzjerstwo, kowalstwo). Należałoby jednak w tym miejscu dopowiedzieć, że operowanie wspólną nazwą może być mimo wszystko kłopotliwe, jeśli weźmiemy pod uwagę sygnalizowany przez Ewę Pajewską (2003: 16, przypis 3) problem istnienia kodów, które nie odnoszą się do teorii naukowych ${ }^{14}$ (np. język szewców) lub nie są stosowane w komunikacji pisanej (np. język zdunów) (por. Kiklewicz 2009: 74).

Przywołane propozycje usytuowania nazwy język zawodowy w polskim systemie terminologicznym i jej definiowania nie są w polskim piśmiennictwie rzadkością, gdyż pojęcie to stanowiło stały element rozmaitych typologii odmian polszczyzny (np. Klemensiewicz 1953). Obecnie jednak wyrażenie to najczęściej używane jest intuicyjnie i rzadko podlega precyzującemu objaśnianiu. Podobna sytuacja dotyczy sformułowania język fachowy, gdyż lingwiści właściwie nie podejmują próby określenia jego za-

${ }^{13}$ Wolfgang Walter Menzel proponował natomiast, by język nauki traktować jako JĘZYK ZAWODOWY NAUKI stanowiący kohiponim JĘZYKA ZAWODOWEGO POTOCZNEGO (podaję za: Pajewska 2003: 21). W tym ujęciu więc JĘZYK ZAWODOWY stanowiłby dla JĘZYKA NAUKOWEGO kategorię nadrzędną.

${ }^{14}$ Pomocne mogłoby się okazać w tej sytuacji zaproponowane przez Sambora Gruczę (2008: 5) rozróżnienie na KOGNITYWNE JĘZYKI SPECJALISTYCZNE Związane z pracą poznawczą i PRAKTYCZNE JĘZYKI SPECJALISTYCZNE związane z pracą praktyczną (por. Gajda 1990: 36-37). Można mieć jednak wątpliwości, czy da się rozdzielić oba zjawiska. Czy kognitywne JS nie są bowiem stosowane w praktyce? Czy z kolei praktyczne JS funkcjonują w oderwaniu od sfery kognitywnej? Wydaje się, że na oba pytania należałoby udzielić odpowiedzi negatywnej. Podobne wnioski nasuwają się w odniesieniu do podziału języków specjalistycznych na TEORETYCZNO-FACHOWE i PRAKTYCZNO-FACHOWE (Dickel 2007: 99). 
kresu pojęciowego. Zdarza się jednak stawianie znaku równości między obiema nazwami poprzez ich wyliczenie po przecinku lub umieszczenie jednej z nich w nawiasie, sugerujące dodatkowo tożsamość znaczeniową tych form z terminem język specjalistyczny ${ }^{15}$ (np. język specjalistyczny (fachowy, zawodowy itd.); Kubiak 2002: 6; por. Wilkoń [1987] 2000: 86; Ligara 2011: 169).

Jednym z ciekawszych, choć odosobnionych w literaturze ujęć jest sformułowana przez Tadeusza Zgółkę (2010: 37-38) propozycja uznania języka zawodowego \|fachowego za kod używany prymarnie do konstruowania tekstów pisanych i określania zarazem jego ,potocznej”, ekspresywnej wersji stosowanej w komunikacji ustnej mianem żargonu. Zgodnie z przywołanym rozróżnieniem — przykładowo — formy terminologiczne dotyczące anatomii, fizjologii czy schorzeń stosowane w piśmiennictwie naukowym należałoby nazywać medycznym językiem zawodowym \|fachowym, a zrozumiałe dla pacjenta leksykalne odpowiedniki terminów — żargonem lekarskim. Oznaczałoby to zatem, że wyrażenia język zawodowy i język fachowy pokrywałby się zakresowo z nazwą język specjalistyczny, skoro określane nią kody zbudowane są jak wspomniałam wcześniej — z leksyki terminologicznej. Propozycja odróżnienia JĘZYKA ZAWODOWEGO || JĘZYKA FACHOWEGO od ŻARGONU wydaje się jednak zbyt uproszczona, gdyż każdy lekarz w rozmowach zarówno ze współpracownikami, jak i z pacjentami musi operować terminami medycznymi typu grasica, endometrium, arytmia czy brodawczak skóry. Trudno zresztą byłoby znaleźć potoczne ekwiwalenty leksykalne, które precyzyjnie desygnowałyby organy, wydzieliny czy jednostki chorobowe (por. Doroszewski 2010). Argumenty te przemawiają moim zdaniem za niemożnością kategorycznego przyporządkowania zbioru form terminologicznych do komunikacji pisanej, a ich ekspresywnych odpowiedników — do ustnej, co tym samym stawia pod znakiem zapytania właściwość kryterium, na podstawie którego dokonano rozróżnienia JĘZYK ZAWODOWY $\|$ JĘZYK FACHOWY $\neq$ ŻARGON.

W piśmiennictwie lingwistycznym słabo rozpowszechnione są natomiast objaśnienia określeń język specjalny oraz język profesjonalny. Pierwsza z nazw, która funkcjonowała na polskim gruncie już w latach 40. XX w. (Milewski 1947), bywa rozumiana na trzy sposoby. Badacze utożsamiają ją bowiem z (1) socjolektami (Ligara 2011), (2) językami tajnymi, czyli żargonami (Geremek 1980), wreszcie z (3) językami specjalistycznymi (Chłopicka-Wielgos, Pukas-Palimąka 1996; por. Chludzińska 1950). Kojarzenie omawianego wyrażenia z różnymi zjawiskami świadczy bez wątpienia o rozmytych granicach pojęcia, które w dodatku rzadko staje się przedmiotem definiowania w literaturze ${ }^{16}$.

${ }^{15}$ Być może semantyczne utożsamianie nazw język fachowy i język specjalistyczny należy genetycznie wyprowadzać z wyraźnego podobieństwa leksykalnego polskich form fach i fachowy do niemieckich wyrazów Fach ('specjalność, dziedzina') oraz fachlich ('specjalistyczny, fachowy').

${ }^{16}$ Warto w tym miejscu przywołać zaaplikowaną na grunt polski przez Annę Godzich (2014) interesującą koncepcję włoskiego lingwisty Alberta A. Sobrera, który biorąc pod uwagę poziom specjalizacji, podzielił JĘZYKI SPECJALNE na JĘZYKI SPECJALISTYCZNE (ścisłe, silnie sterminologizowane, np. medycyna, fizyka) oraz JĘZYKI DZIEDZINOWE (słabo wyspecjalizowane, choć związane z działalnością zawodową, np. polityka, telewizja). 
Z kolei w przypadku wyrażenia język profesjonalny trudno właściwie jednoznacznie stwierdzić, czy nazwa ta posiada status terminu, gdyż najprawdopodobniej nie podjęto dotychczas próby jego objaśnienia. W nowszych opracowaniach przyjmuje się, że formę tę wprowadził do dyskursu naukowego Jan Lewandowski (2002), i pomija się tym samym fakt, że już w latach 70. ubiegłego stulecia posługiwali się nią Andrzej Piotrowski i Marek Ziółkowski (1976: 111), obejmując jej zakresem wyróżnione przez Antoniego Furdala (1973) języki: NAUKOWY PISANY, NAUKOWY MÓWIONY, ZAWODOWY MIEJSKI i ZAWODOWY WIEJSKI. Takie zastosowanie pozwala zatem przyjąć, że omawiane wyrażenie badacze traktowali jako nadrzędne względem JĘZYKA NAUKOWEGO i JĘZYKA ZAWODOWEGO. Trzeba jednak wyraźnie zaznaczyć, że w przywoływanym opracowaniu Piotrowski i Ziółkowski nie zdefiniowali nazwy język profesjonalny, dlatego trudno ustalić, czy używali jej w funkcji terminologicznej. Obecnie natomiast forma ta stanowi najczęściej składnik ciągów wyliczeniowych obejmujących zespolenia język zawodowy i język specjalistyczny (Pajewska 2003) albo stosowana jest zamiennie z ostatnim z tych określeń (np. Lewandowski 2002; Sawicka A. 2009). Taki sposób użycia świadczy z kolei o traktowaniu wszystkich trzech sformułowań jako znaczeniowo tożsamych.

Przegląd polskojęzycznych rozpraw pozwala zatem stwierdzić, że w zasadzie jedynie relacja semantyczna między pojęciami JĘZYK SPECJALISTYCZNY - TECHNOLEKT oraZ JĘZYK ZAWODOWY - JĘZYK FACHOWY nie budzi wątpliwości, gdyż badacze są zgodni co do ich równoznaczności. Związki między pozostałymi interesującymi mnie nazwami nie są natomiast — jak starałam się wykazać — jednomyślnie określane. JĘZYK SPECJALISTYCZNY w stosunku do PROFESJOLEKTU czasem uznawany jest za tożsamy, czasem za odrębny. Relację JĘZYK SPECJALISTYCZNY — JĘZYK ZAWODOWY postrzega się jako ekwiwalencję albo hierarchię. Niejednorodnie ujmuje się także pozycję JĘZYKA PROFESJONALNEGO WZględem JĘZYKA ZAWODOWEGO, gdyż oba pojęcia traktowane są jako zamienne zakresowo, ale bywają też traktowane jako — odpowiednio - hiperonim i hiponim. Wreszcie JĘZYK SPECJALNY utożsamia się z trzema różnymi fenomenami, a JĘZYK ZAWODOWY i JĘZYK FACHOWY uznaje się za tożsame zarówno z JĘZYKIEM SPECJALISTYCZNYM, jak i z PROFESJOLEKTEM. Stopień skomplikowania problematyki jest zatem bez wątpienia poważny, co uniemożliwia skonstruowanie przejrzystego i kompletnego diagramu obrazującego zakresy poszczególnych pojęć. Chcąc jednak zobrazować możliwe ujęcia, jakie wyłaniają się z proponowanych w literaturze rozstrzygnięć, należałoby zbudować właściwie cztery modele (ryc. 3). Należy jednak wyraźnie zaznaczyć, że zamieszczone poniżej schematy stanowią uproszczoną (być może nazbyt swobodną) konfigurację różnych przywołanych powyżej koncepcji. Z tego też powodu żadnego z nich nie dałoby się opatrzyć przypisem odsyłającym do konkretnego źródła. Celem zbudowania tych diagramów była natomiast chęć zilustrowania skrajnych odmienności w postrzeganiu relacji między analizowanymi pojęciami, a tym samym odzwierciedlenia rozległości problemów terminologicznych. 


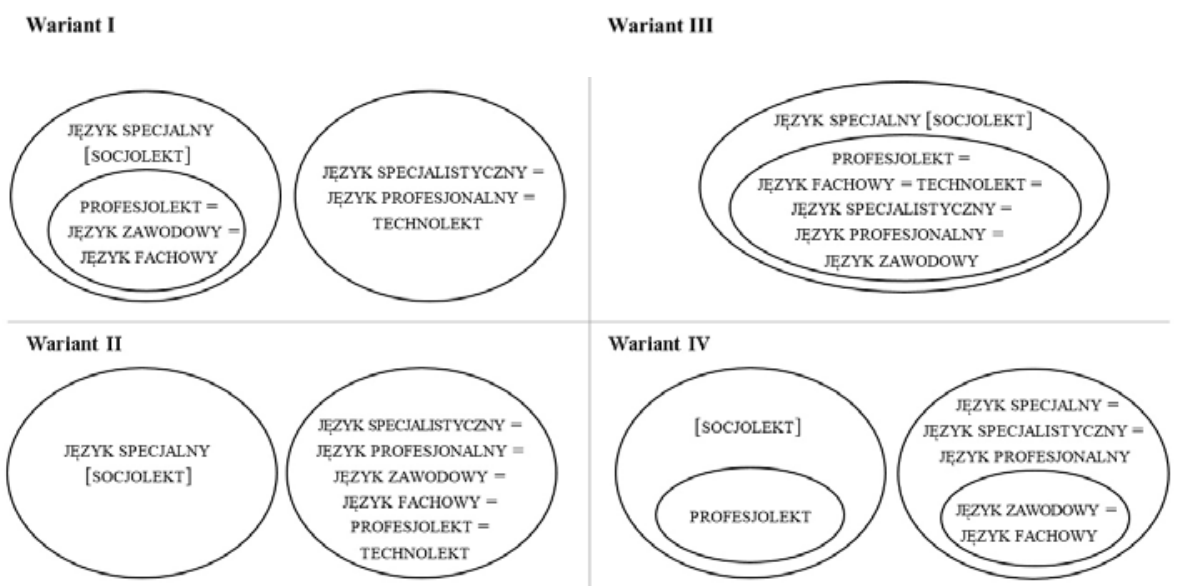

Ryc. 3. Zakresy badanych pojęć (na podstawie analizy opracowań lingwistycznych).

Źródło: opracowanie własne.

\section{Diagnoza i propozycja}

Analiza semantyczna form: język specjalistyczny,język specjalny, język fachowy, język profesjonalny, języ zawodowy, profesjolekt, technolekt, przeprowadzona na trzech typach danych, pozwala stwierdzić, że badane pojęcia bez wątpienia nie są tożsame. Ustabilizowane w polszczyźnie ogólnej znaczenia przymiotników stanowiących składniki wymienionych wyrażeń oraz członów profesjo- oraz techno- pozwoliły na określenie konkretnych relacji między zakresami poszczególnych nazw. Z kolei interpretacja objaśnień zawartych w słownikach przybliżających definicje terminów językoznawczych, a przede wszystkim analiza sposobu użycia i rozumienia omawianych form w opracowaniach lingwistycznych obnażyła w pełni problem odnoszenia interesujących mnie sformułowań do różnych zjawisk językowych. Wyraźnie dostrzegalna jest także niejednomyślność badaczy w określaniu zarówno granic, jak i relacji pojęciowych. Chaos terminologiczny klarownie zobrazuje macierz, na której zaznaczono wskazywane przez lingwistów rodzaje relacji łączących zakresy poszczególnych nazw — zamienność, nadrzędność, podrzędność, wykluczanie się. Nawiązując do poprzednich schematów i mając na uwadze ścisły związek omawianych form z terminem socjolekt, uwzględniono go w podsumowującym diagramie (ryc. 4).

Bronisława Ligara (2011: 167) konstatuje, że nadmiar terminów będących przedmiotem analiz w niniejszym tekście wynika z niezdecydowania badaczy co do kryterium, na podstawie którego należy wyodrębniać z krajobrazu językowego poszczególne typy kodów. Wyrażeniami język zawodowy, język fachowy i profesjolekt uwypukla się bowiem jej zdaniem związek narzędzia komunikacji z zawodem, profesją, z kolei za pomocą form język specjalny, język specjalistyczny sygnalizuje się odniesienie do 


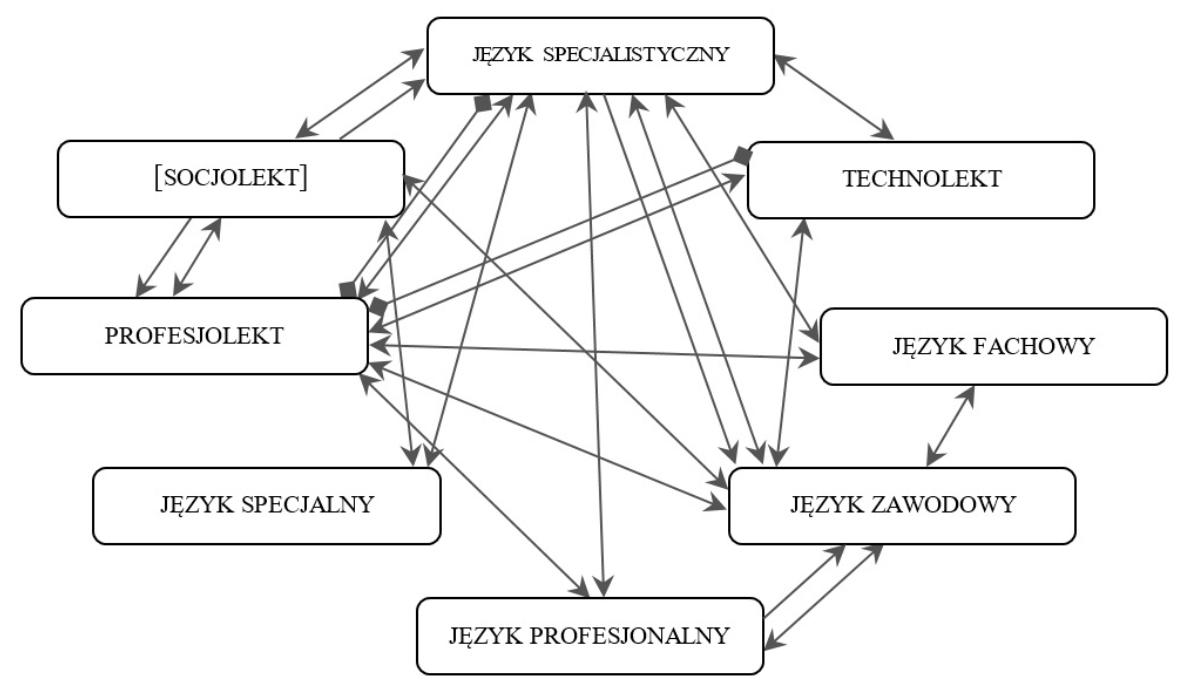

Ryc. 4. Relacje między zakresami badanych pojęć (podsumowanie).

Źródło: opracowanie własne.

Legenda: $\leftrightarrow$ zamienność; $\rightarrow$ podrzędność (grot strzałki wskazuje hiponim); $\bullet$ wykluczanie się.

specjalności, tj. dyscypliny nauki lub techniki oraz innej działalności, w której trzeba być specjalista z danego zakresu ${ }^{17}$. Przywołane powyżej rozmaite, nieraz skrajnie odmienne stanowiska świadczą jednak o tym, że problem z semantycznym różnicowaniem nazw jest o wiele bardziej skomplikowany i jeden tekst to z pewnością zbyt mało, by uporządkować tak poważny bałagan. Niejednomyślność w rozumieniu poszczególnych terminów wynika bowiem przede wszystkim z wielości perspektyw oglądu zjawisk językowych. Wszelkie rozróżnienia i typologie są wszak konstruowane w oparciu o różne kryteria (np. Grynkiewicz 1990; Kiklewicz 2009), co przekłada się na formułowanie konkurencyjnych, nieraz koncepcyjnie bardzo odległych propozycji. Wyraźnie obrazuje to zresztą opisany powyżej problem relacji łączących JĘZYK SPECJALISTYCZNY, JĘZYK ZAWODOWY i JĘZYK NAUKOWY. Prawdą jest też, że kłopoty nomenklaturowe są również pochodną zarówno nadmiernego upraszczania bądź pomijania istotnych aspektów cechujących rozmaite fenomeny, jak i utożsamiania polskich nazw z podobnie brzmiącymi terminami funkcjonującymi na gruncie angielskim czy niemieckim (np. language for special purposes $\leftrightarrow$ język specjalny). Nie można w dodatku zapomnieć o licznych niestety przypadkach intuicyjnego, bezrefleksyjnego czy wręcz trywialnego posługiwania się omawianymi tu nazwami, co oczywiście niewiele ma wspólnego z pożądanym u lingwisty puryzmem terminologicznym.

\footnotetext{
${ }^{17}$ Lingwistka nie podejmuje niestety próby określenia zakresów przywoływanych przez siebie nazw język fachowy, język profesjonalny, technolekt.
} 
Analiza literatury przedmiotu wykazała również, że wybrany przeze mnie dosyć pokaźny zbiór nazw odnoszonych do kodów stanowiących narzędzie komunikacji w środowiskach zawodowych nie jest kompletny, gdyż należałoby go uzupełnić szeregiem innych określeń, często nieostrych i zwykle niemających charakteru terminologicznego. Autorzy słowników oraz opracowań rozszerzają bowiem znacznie kontekst leksykalny, operując również przywołanymi powyżej formami typu język naukowy, język techniczny czy argot profesjonalny. Dodatkowo w rozmaitych rozprawach stosuje się inne nazwy, mniej lub bardziej utrwalone w dyskursie lingwistycznym: język branżowy, język dziedzinowy, język sektorowy ${ }^{18}$, język sekundarny, język specyficzny, język specjalistyczno-zawodowy, techniczno-naukowy język specjalistyczny, technolekt naukowy, język do zadań specjalnych, język dla celów specjalistycznych, język tekstów specjalistycznych, gwara profesjonalna, subjęzyk specjalizowany, styl specjalistyczny, żargon profesjonalny, styl fachowy, styl techniczny (Chłopicka-Wielgos, Pukas-Palimąka 1996: 70; Pajewska 2003: 17; Kiklewicz 2006: 100; 2009: 79; Karpiński 2008: 12; Żarski 2008: 155; Grygoruk 2009: 62, przypis 1; Grucza S. 2010: 50; Szadyko 2013: 16; Gajewska, Sowa 2014: 18; Smól 2015: 56; Gonigroszek 2017: 186, przypis 1). Co więcej, wciąż można zaobserwować używanie terminów gwara, żargon czy — ogólnie socjolekt $\mathrm{w}$ odniesieniu do omawianych wariantów języka (por. Jarosz 2016). Oznacza to zatem, że polscy językoznawcy są jeszcze wciąż na początku drogi, którą z sukcesem przebyli niemieccy badacze - z kilkudziesięciu onimów wybrali bowiem ostatecznie Fachsprache i — jak informuje Sambor Grucza ([2004] 2013: 16) — w dyskusjach naukowych posługują się właściwie wyłącznie tą nazwą.

Opisany w niniejszym tekście zamęt nomenklaturowy skłonił mnie do podjęcia próby uporządkowania badanych pojęć. Na podstawie dokonanej analizy postulowałabym, aby formy język specjalistyczny oraz technolekt niezmiennie traktować jako synonimy dokładne (równoznaczniki) oznaczające kody zbudowane z terminologii naukowo-technicznej właściwej dla określonej dziedziny nauki lub techniki (np. medycyna, chemia, architektura, lotnictwo). Rzeczownik profesjolekt proponowałabym natomiast odnosić do tych wariantów języka, które poza terminologią naukowo-techniczną posiadają $\mathrm{w}$ zasobie leksykalnym spory zbiór swoistego słownictwa ekspresywnego, odnoszącego się do zjawisk typowych w określonym środowisku zawodowym (np. dziennikarze posługujący się w codziennej komunikacji zarówno terminami z zakresu medioznawstwa, filmoznawstwa, tekstologii, edytorstwa, poligrafii, jak i ich wartościującymi odpowiednikami). Upraszczając zatem sformułowane rozróżnienie: pojęcie JĘZYK SPECJALISTYCZNY należałoby łączyć z dokładnym, ścisłym nazywaniem fenomenów w obrębie różnych dziedzin nauki lub techniki (np. język chemiczny ('chemii'), muzyczny ('muzyki')), PROFESJOLEKT natomiast - z precyzyjno-ekspresywnym określaniem zjawisk związanych z daną profesją lub jakimś rodzajem działalności wymagającej pewnych kwalifikacji (np. język chemików, muzyków, alpinistów, sportow-

${ }^{18}$ Nazwa język sektorowy jest kalką włoskiego lingue settoriali (por. Taino 1995: 3; Kaliska 2018: 20). 
ców $)^{19}$. Obecność warstwy terminologicznej w obu wymienionych typach kodów oznacza natomiast, że JĘZYKI SPECJALISTYCZNE i PROFESJOLEKTY należy postrzegać jako pojęcia zakresowo się krzyżujące. Można bowiem wskazać takie języki specjalistyczne, które funkcjonują właściwie wyłącznie w obiegu naukowym (np. w astrofizyce czy geochemii), oraz profesjolekty niezawierające terminów w zasobie leksykalnym (np. kod grabarzy).

Kolejne zespolenia — język fachowy i język zawodowy — zarówno ze względu na znaczenie przymiotników fachowy oraz zawodowy, jak i w oparciu o rozstrzygnięcia zawarte w literaturze proponuję traktować jako ekwiwalenty terminu profesjolekt. $\mathrm{Z}$ uwagi na to, że wyrażenie język zawodowy sugeruje związek z profesją, nie należałoby go wiązać relacją synonimiczności z nazwą język specjalistyczny. Z kolei polisemiczność pierwszego z przywołanych adjektywów uprawniałaby traktowanie nazwy język fachowy za zakresowo tożsamą z pojęciem JĘZYK SPECJALISTYCZNY. Wreszcie w odniesieniu do określeń język specjalny i język profesjonalny sugerowałabym ostrożne operowanie tymi sformułowaniami ze względu na ich niejednoznaczność i nieostrość. Dobrym rozwiązaniem w tym przypadku byłoby (rzadko praktykowane) precyzowanie znaczenia, w jakim używa się tych nazw. Mając na względzie przejrzystość proponowanego rozróżnienia terminologicznego, skonstruowałam schemat (ryc. 5), na którym zakresy dwóch ostatnich wyrażeń zaznaczyłam linią przerywaną, uwypuklając w ten sposób ich niewyrazistość semantyczną. Wyrażenie język fachowy zapisałam natomiast kursywą, wskazując w ten sposób możliwość używania tej formy w dwojakim znaczeniu.

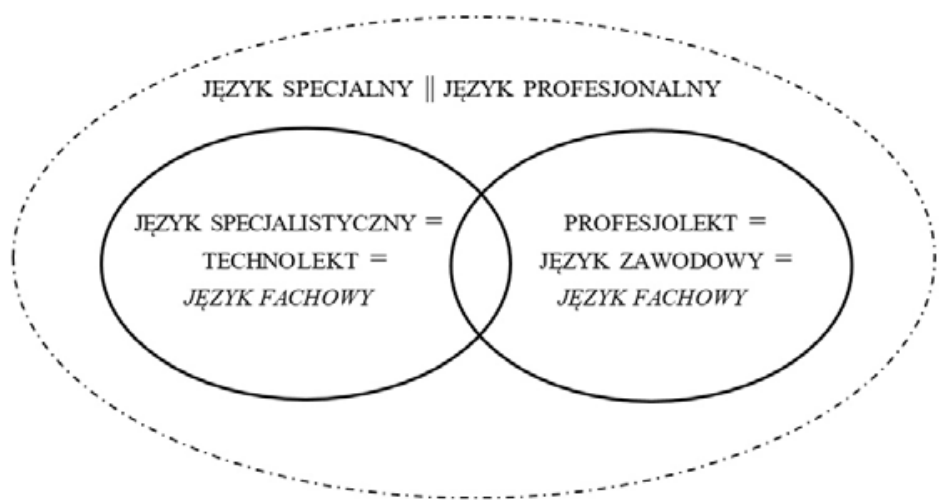

Ryc. 5. Zakresy badanych pojęć wyznaczone na podstawie przeprowadzonych analiz (propozycja). Źródło: opracowanie własne.

${ }^{19}$ Sądzę, że takie rozróżnienie jest uzasadnione również łączliwością wyrażenia język specjalistyczny i odpowiadającego mu rzeczownika technolekt. Zespolenia język specjalistyczny matematyki, biologii czy lingwistyki wydają się typowe, poprawne, fortunne, w odróżnieniu od wręcz groteskowych nazw *język specjalistyczny grabarzy czy *język specjalistyczny hotelarzy. Analogiczna sytuacja dotyczy terminu technolekt — o ile połączenia technolekt medyczny, chemiczny czy informatyczny nie budzą żadnych wątpliwości, o tyle sformułowania technolekt aktorów, tancerzy czy muzyków mogą sprawiać wrażenie nieudanych. 
Oczywiście mam świadomość, że obfitość literatury poświęconej kodom używanym w komunikacji profesjonalnej czy specjalistycznej może działać na niekorzyść wdrożenia proponowanych uściśleń. Nie da się masowo zmodyfikować istniejących już rozpraw, więc terminologiczny chaos w nich pozostanie. Można mieć jednak nadzieję, że zaproponowana w niniejszym tekście semantyczna konkretyzacja wybranych terminów zainicjuje pogłębioną refleksję nad omówionym problemem i przyczyni się do wytyczenia wyraźnych granic między zakresami poszczególnych nazw, a tym samym do uściślenia aparatu pojęciowego.

\section{Bibliografia}

\section{Słowniki}

Doroszewski W., 1965, Słownik języka polskiego, t. 7, Warszawa.

Dubisz S. (red.), 2003, Uniwersalny słownik języka polskiego, t. 1-4, Warszawa.

Gołąb Z., Heinz A., Polański K., 1970, Słownik terminologii językoznawczej, Warszawa.

Lukszyn J. (red.), 1993, Tezaurus terminologii translatorycznej, Warszawa.

— [2002] 2005, Języki specjalistyczne. Słownik terminologii przedmiotowej, wyd. 2, uzup., Warszawa. Polański K. (red.), [1993] 2003, Encyklopedia językoznawstwa ogólnego, Wrocław, wyd. 3.

Rudnik-Karwatowa Z., Karpińska H., 1999, Słownik słów kluczowych językoznawstwa slawistycznego, Warszawa.

Skudrzykowa A., Urban K., 2000, Mały słownik terminów z zakresu socjolingwistyki i pragmatyki językowej, Kraków-Warszawa.

Szulc A., 1984, Podręczny słownik językoznawstwa stosowanego. Dydaktyka języków obcych, Warszawa.

\section{Opracowania}

Appel K., 1908, Język i społeczeństwo. (Lingwistyka i socyologia), Warszawa.

Chłopicka-Wielgos M., Pukas-Palimąka D., 1996, Nauczanie języka specjalistycznego, a nie tylko terminologii, Acta Universitatis Lodziensis. Kształcenie Polonistyczne Cudzoziemców 7/8, s. 69-80.

Chludzińska J., 1950, Z dziejów polskiego słownictwa plastycznego, Poradnik Językowy 2, s. 18-24.

Dąbkowski G., 2010, Język muzyków — profesjolekt czy socjolekt?, [w:] Polskie języki. O językach zawodowych i środowiskowych. Materiały VII Forum Kultury Słowa. Gdańsk, 9-11 października 2008 roku, red. M. Milewska-Stawiany, E. Rogowska-Cybulska, Gdańsk, s. 354-360.

Danesi M., 1985, A Glossary of Lectal Terms for the Description of Language Variation, Language Problems and Language Planning 9 (2), s. 115-124.

Dickel A., 2007, Klasyfikacja głównych kierunków badawczych podejmujących problem relacji między językami specjalistycznymi i językiem ogólnym ze szczególnym uwzględnieniem badań nad niemieckimi językami specjalistycznymi, [w:] Teksty specjalistyczne jako nośniki wiedzy fachowej, red. M. Kornacka, Języki Specjalistyczne 7, Warszawa, s. 98-133.

Doroszewski J., 2010, Język nauki i praktyki medycznej, [w:] Polskie języki. O językach zawodowych i środowiskowych. Materiały VII Forum Kultury Słowa. Gdańsk, 9-11 października 2008 roku, red. M. Milewska-Stawiany, E. Rogowska-Cybulska, Gdańsk, s. 299-319.

Furdal A., 1973, Klasyfikacja odmian współczesnego języka polskiego, Wrocław.

Gajda S., 1982, Podstawy badań stylistycznych nad językiem naukowym, Warszawa.

— 1990, Współczesna polszczyzna naukowa. Język czy żargon?, Opole. 
— 1997, Polskie języki specjalistyczne dawniej i dziś, [w:] Języki specjalistyczne. Język biznesu, red. J. Arabski, Katowice, s. 7-24.

— 2005, Zróżnicowanie języka jako problem metodologiczny, [w:] Spotkanie. Księga jubileuszowa dla Profesora Aleksandra Wilkonia, red. M. Kita, B. Witosz, Katowice, s. 72-81.

Gajewska E., Sowa M., 2014, LSP, FOS, Fachsprache. Dydaktyka języków specjalistycznych, Lublin.

Geremek B., 1980, O językach tajemnych, Teksty 2(50), s. 13-36.

Giers U., 2017, Sprache und Region in der Sekundarstufe I, [w:] Region — Sprache — Literatur Unterrichtsanregungen und Materialien für den Deutschunterricht in der Primar- und Sekundarstufe, red. E. Berner, Poczdam, s. 77-91.

Godzich (Szemberska) A., 2014, Przenikanie się języków specjalnych w polskich mediach — płynna nowoczesność czy skuteczniejsza komunikacja?, [w:] (Ko)media. Konteksty dyskursu medialnego, red. J. Goluchowski, D. Konieczna, K. Zdanowicz-Cygan, Warszawa, s. 121-129.

Gonigroszek D., 2017, Polska terminologia medyczna - spojrzenie diachroniczne, [w:] Bogactwo językowe i kulturowe Europy w oczach Polaków i cudzoziemców, t. 4, red. R. Maćkowiak, R. Wojtczak, Łódź, s. 185-192.

Grabias S., 1974, Funkcyjna klasyfikacja socjalnych wariantów języka, Język Polski 54, s. 22-31.

— [1994] 2003, Język w zachowaniach społecznych, Lublin.

Grucza F., 1991, Teoretyczne podstawy terminologii, Problemy Terminologii 1, Wrocław.

— 1993, Język, ludzkie właściwości językowe, językowa zdolność ludzi, [w:] Człowiek w perspektywie ujęć biokulturowych, red. J. Piontka, A. Wiercieńska, Poznań, s. 151-174.

— 1994, O językach specjalistycznych (= technolektach) jako pewnych składnikach rzeczywistych języków ludzkich, [w:] Języki specjalistyczne, red. F. Grucza, Z. Kozłowska, Warszawa, s. 7-27.

— 2002, Języki specjalistyczne — indykatory i/lub determinanty rozwoju cywilizacyjnego, [w:] Problemy technolingwistyki, red. J. Lewandowski, Warszawa, s. 9-26.

Grucza S., 2008, Lingwistyka języków specjalistycznych, Warszawa.

— 2010, Główne tezy antropocentrycznej teorii języków, Lingwistyka Stosowana 2, s. 41-78.

- [2004] 2013, Od lingwistyki tekstu do lingwistyki tekstu specjalistycznego, Warszawa.

Grygoruk A., 2009, Uwarunkowania kulturowe w dydaktyce języka specjalistycznego (na przykładzie języka sfery podatkowej i okołopodatkowej cz. I), Linguodidactica 13, s. 53-65.

Grynkiewicz M., 1990, Próba klasyfikacji odmian współczesnego języka polskiego, [w:] Język — teoria — dydaktyka. Materiały IX Konferencji Młodych Językoznawców-Dydaktyków, red. M. Preyzner, Kielce, s. 27-36.

Hejwowski K., 2001, Języki specjalistyczne a kompetencja tłumaczeniowa, [w:] Języki fachowe — problemy dydaktyki i translacji, red. A. Kątny, Olecko.

Janasowa J., 1979, Słownictwo techniczne w akcie mowy, Socjolingwistyka 2, s. 183-194.

Jaros V., 2013, Źródła leksyki socjolektu użytkowników CB-radia, Rozprawy Komisji Językowej ŁTN 59, s. $61-77$.

Jarosz B., 2016, Typologie socjolektów w polskiej literaturze językoznawczej. Implikacje terminologiczne, [w:] Tradycja i współczesność w języku i literaturze, Badania nad językiem i kulturą 1, red. S. Gaś, D. Kalecińska, S. Wawrzyniak, Poznań, s. 139-155.

Kaliska M., 2018, Podejście działaniowe w dydaktyce thumaczenia specjalistycznego, [w:] Specyficzne potrzeby studentów szkół wyższych a nauczanie języków obcych, t. 2: Praktyczne narzędzia, red. M. Jedynak, Wrocław, s. 14-31.

Karpiński Ł., 2008, Zarys leksykografii terminologicznej, Warszawa.

Karpiński Ł., Michałowski P., 2012, Wybrane metody analizy terminologii specjalistycznej (na przykładzie technolektu geografii), Edukacja dla Przyszłości 9, s. 23-26.

Karwatowska M., Jarosz B., 2013, Specyfika komunikacji profesjonalnej, [w:] Komunikacja — tradycja i innowacje, red. M. Karwatowska, A. Siwiec, Chełm, s. 102-116.

Kijak A., 2015, O istotnych aspektach biegania w świetle leksyki socjolektalnej (na podstawie artykułów poświęconych treningom, zamieszczonych na portalach biegowych), Poznańskie Studia Polonistyczne. Seria Językoznawcza 22, nr 2, s. 169-182. 
Kiklewicz A., 2006, Język, komunikacja, wiedza, Mińsk.

— 2007, O funkcji stylistycznej wypowiedzenia, Acta Neophilologica 9, s. 19-30.

— 2009, Warianty języka: próba systematyzacji, Biuletyn Polskiego Towarzystwa Językoznawczego 65, s. $67-83$.

Klemensiewicz Z., 1953, O różnych odmianach współczesnej polszczyzny, Warszawa.

Kołodziejek E., 2010, Społeczne i kulturowe uwarunkowania współczesnych odmian zawodowych (na przykładzie profesjolektów marynarzy, żołnierzy i policjantów), [w:] Polskie języki. O językach zawodowych i środowiskowych. Materiały VII Forum Kultury Słowa. Gdańsk, 9-11 października 2008 roku, red. M. Milewska-Stawiany, E. Rogowska-Cybulska, Gdańsk, s. 106-116.

Kryżan-Stanojević B., Sychowska-Kavedžija J., 1996, Zastosowanie trzeciego kodu językowego jako pomoc w nauce języka specjalistycznego, Acta Universitatis Lodziensis. Kształcenie Polonistyczne Cudzoziemców 7/8, s. 53-67.

Kubiak B., 2002, Pojęcie języka specjalistycznego, Języki Obce w Szkole 5, s. 6-11.

Kuć J., 2011, Nowe profesjolektalne słownictwo polskie (na przykładzie języka zawodowego menedżerów i trenerów), [w:] Vidy jazyka a jazykovedy. Venovanú životnému jubileu doc. PhDr. Miloslavy Sokolovej, CSc., red. M. Ološtiak, M. Ivanova, D. Slančova, Prešov, s. 348-360.

Lesicka O., 2015, Anglojęzyczne zapożyczenia terminologiczne w rosyjskich czasopismach ekonomicznych przełomu XX i XXI wieku, Warszawa.

Lewandowski J., 2002, Paratypologie i quasi-klasyfikacje polskich języków profesjonalnych, [w:] Problemy technolingwistyki, red. J. Lewandowski, Warszawa, s. 27-40.

Ligara B., 2011, Relacje między językiem ogólnym a językiem specjalistycznym w perspektywie językoznawstwa polonistycznego, stosowanego i glottodydaktyki, LingVaria 6, nr 2(12), s. 163-181.

Lukszyn J., 2009, W kwestii pojęcia „,tekst specjalistyczny”, Komunikacja Specjalistyczna 1, s. 7-13.

Marcjanik M., 2008, Kody grzeczności jako forma identyfikacji z grupą, Kultura Współczesna. Teorie. Interpretacje. Praktyka 2, s. 71-76.

Milewski T., 1947, Język a społeczeństwo, Lublin.

Nagy I.K., 2014, English for Special Purposes: Specialized Languages and Problems of Terminology, Acta Universitatis Sapientiae. Philologica 6 (2), s. 261-273.

Niepytalska-Osiecka A., 2014, Socjolekt polskich alpinistów. Analiza leksykalno-semantyczna słownictwa, Kraków.

Ohly R., 2002, Procesy tworzenia się języków specjalistycznych (LSP) w językach afrykańskich, [w:] Problemy technolingwistyki, red. J. Lewandowski, Warszawa, s. 49-63.

Ożdżyński J., 1996, Profesjonalizmy, subjęzyki i rejestry — w ujęciu kognitywnym, [w:] Wokół społecznego zróżnicowania języka, red. S. Kania, Szczecin, s. 125-140.

Pajewska E., 2003, Słownictwo tematycznie związane z lasem w kontekście badań nad językami specjalistycznymi, Szczecin.

Pędzich B., 2012, Jak powstaje socjolekt? Studium słownictwa paralotniarzy, Warszawa.

Piekot T., 2008, Język w grupie społecznej. Wprowadzenie do analizy socjolektu, Wałbrzych.

Piotrowski A., Ziółkowski M., 1976, Zróżnicowanie językowe a struktura społeczna, Warszawa.

Pytel F., 2004, Słownictwo fachowe jako identyfikator LSP, [w:] Leksykografia terminologiczna - teoria i praktyka, red. J. Lewandowski, Języki Specjalistyczne 4, Warszawa, s. 101-110.

Reduta M., 2015, Zawód, profesja i kultura profesjonalna, Optimum. Studia Ekonomiczne 2 (74), s. 100-118.

Sawicka A., 2009, Krótka charakterystyka języków specjalistycznych, Komunikacja Specjalistyczna 2 , s. $188-198$.

Sawicka G., 2006, Język a konwencja, Bydgoszcz.

Skyum-Nielsen P., 1978, Language Problems and Language Treatment in Danish Speech Community, Language Planning Newsletter 4, nr 1, s. 1-5.

Smól J., 2015, Profesjolekt hotelarski w mediach na przykładzie pisma menedżerów hoteli — „Biznes hotel", Investigationes Linguisticae 33, s. 55-67.

Szadyko S., 2013, Metodyka thumaczenia skrótowców morfologicznych w rosyjskich i polskich tekstach specjalistycznych, [w:] W dialogu języków i kultur III, red. K. Fordoński, Ł. Karpiński, Warszawa, s. 11-24. 
Taino P., 1995, Le lingue settoriali del tedesco, Traduzione, Società e Cultura 6, s. 1-90.

Tokarski R., 1977, Uwagi o gwarze wędkarskiej, Poradnik Językowy 3, s. 111-121.

Trzaskawka P., 2014, Przyczynek do charakterystyki języka muzyki, Investigationes Linguisticae 31, s. $57-70$.

Vanneste A., 2005, Le français du XXIe siècle. Introduction à la francophonie. Éléments de phonétique, de phonologie et de morphologie, Antwerpia-Apeldoorn.

Wilkoń A., [1987] 2000, Typologia odmian językowych współczesnej polszczyzny, Katowice, wyd. 2, popr.

Zgółka T., 2010, Parametry odróżniające odmiany językowe, [w:] Polskie języki. O językach zawodowych i środowiskowych, red. M. Milewska-Stawiany, E. Rogowska-Cybulska, Gdańsk, s. 34-40.

Żarski W., 2008, Książka kucharska jako tekst, Wrocław.

Żydek-Bednarczuk U., 1987, Sytuacja socjolingwistyczna w języku zawodowym na Śląsku, Socjolingwistyka 7, s. 92-105.

\section{SUMMARY}

On the (non-)identity of the concepts: JĘZYK SPECJALISTYCZNY, JĘZYK SPECJALNY, JĘZYK FACHOWY, JĘZYK PROFESJONALNY, JĘZYK ZAWODOWY, PROFESJOLEKT, TECHNOLEKT

Keywords: polish linguistic terminology, language for special purposes, specialist language, special language, expert language, professional language, occupational language, professiolect, technolect.

Słowa kluczowe: polska terminologia lingwistyczna, język specjalistyczny, język specjalny, język fachowy, język profesjonalny, język zawodowy, profesjolekt, technolekt.

The aim of the paper is to analyze the scope of the following terms: język specjalistyczny, język specjalny, język fachowy, język profesjonalny, język zawodowy, profesjolekt, technolekt (language for special purposes, specialist language, special language, expert language, professional language, occupational language, professiolect, technolect), which are used interchangeably in the Polish linguistic literature even though their denotations are not the same. The semantic (in)compatibility of the above terms was investigated in the following stages: (1) explaining the meaning of the expressions without their theoretical context, i.e. the analysis of the meanings of specific components of the terms as established in general Polish; (2-3) interpretation of explanations and specifications functioning in dictionaries containing linguistic terminology and in theoretical studies; (4) formulating a proposal of distinguishing the concepts by defining the scopes of the terms and the relationships between them. 